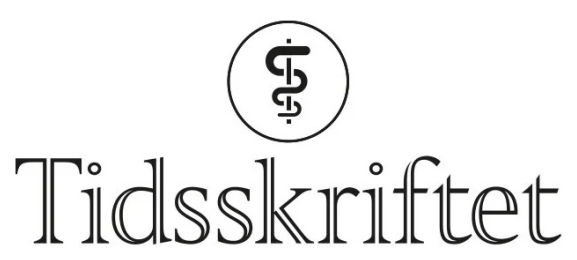

DEN NORSKE LEGEFORENING

\title{
Hvem siterer du?
}

\author{
FRA REDAKTØREN
}

\section{RAGNHILD ØRSTAVIK}

ragnhild.orstavik@legeforeningen.no

Ragnhild Ørstavik er assisterende sjefredaktør i Tidsskriftet. Hun er dr.med. og har en bistilling som forsker ved Folkehelseinstituttet.

\section{Vitenskapen taper på manglende mangfold i akademia.}

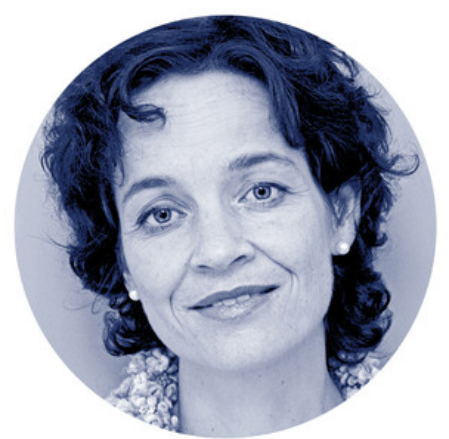

Foto: Einar Nilsen

Litteraturlisten til en vitenskapelig artikkel skal underbygge påstander og lede lesere videre til interessante artikler om samme emne. Siteringer er også viktig for dem som siteres: Ved søknader om tilsetting, opprykk og forskningsmidler kan antall siteringer ha betydning.

Kvinner siteres sjeldnere enn menn, og det skyldes neppe at forskningen de produserer, er dårligere (11). En gjennomgang av mer enn 5 ooo artikler publisert i de seks mest prestisjefylte tidsskriftene innen medisin og helse viste at artikler med kvinnelige forfattere ble sitert inntil halvparten så ofte som menn - og sjeldnere jo flere kvinner det var på de mest betydningsfulle plassene i forfatterrekkefølgen (først eller sist)(1). Førsteforfatter av denne artikkelen, Paula Chatterjee, mener at funnene reflekterer at mennene har større nettverk (2) $)$. Det ser man for eksempel ved at de oftere inviteres til å holde foredrag på medisinske kongresser (3). Men kvinnelige forskere forholder seg nok også mer til janteloven enn sine mannlige kollegaer. De siterer sin egen forskning sjeldnere, og på sosiale medier omtaler de sine forskningsfunn på en mindre spektakulær måte $(4,5)$.

Det kan selvfølgelig være andre årsaker til at kvinner siteres mindre. Kanskje menn publiserer flere metodeartikler (som siteres oftere) enn kvinner, og kanskje kvinnelige forfattere bak en studie var yngre enn mennene og derfor ikke hadde opparbeidet seg like store nettverk? 
Resultatene i denne artikkelen bekrefter imidlertid funn fra tidligere studier, blant annet innen nevrovitenskap. Der er det dokumentert at siteringer i stor grad synes å være drevet av referanselistene fra artikler med menn som første- og sisteforfatter (므). Forskjellene består når man justerer for forfatternes stillingsbetegnelse og fagområde, og ubalansen ser ut til å øke over tid (므). Innen nevrovitenskap er det derfor kommet forslag om retningslinjer for hvordan forfattere kan gå gjennom referanselisten før manuskriptet sendes inn til et tidsskrift: Reflekterer listen kjønnsbalansen innen fagfeltet? Er det noen kvinnelige forskere som bør løftes frem (.7.)?

\section{«Ideer fra marginaliserte grupper fanges ikke opp og blir videreført $i$} samme grad som ideer fra mer privilegerte grupper»

Denne formen for diskriminering rammer nok ikke bare kvinner, men antakelig også andre marginaliserte grupper. Ved The Rockefeller University i USA har en komité som arbeider med mangfold, utarbeidet en veiledning for hvordan man kan øke siteringen av flere underrepresenterte grupper ( $\underline{8})$. Den som har lyst, kan kjøpe en t-skjorte der det står \#citeblackwomen (모).

Det er selvsagt ikke bare individene som lider. Diversitet driver innovasjon (9.). Vitenskapen (og verden) taper på at kvinner og minoritetsgrupper og deres verdensforståelse ikke når frem. Ideer fra marginaliserte grupper fanges ikke opp og blir videreført i samme grad som ideer fra mer privilegerte grupper - og i mindre grad jo mer potensielt nyskapende ideene er (9). Tilhører man en marginalisert gruppe, må man være smartere og rope høyere enn andre for å bli hørt.

Hvordan skal vi så kunne følge med på hvem som publiseres, siteres og premieres, så lenge det ikke er annet enn navn som synes på forfatterlisten? I løpet av de siste årene er det utviklet databaser og metoder som ved hjelp av kunstig intelligens kan klassifisere kjønn basert på navn $(3, \underline{10})$. For å kartlegge andre mulig marginaliserende faktorer må man kanskje rett og slett spørre - uansett hvor ufint det kan oppfattes. Da jeg skulle melde meg på et nettbasert seminar om internasjonal helse nylig, ble jeg spurt: «Har du en funksjonsnedsettelse? Svar slik du opplever deg selv.» Jeg ble også bedt om å oppgi kjønn, etnisitet og seksuell legning, alt som frivillige avkrysningsmuligheter etter at jeg hadde oppgitt navn og e-postadresse.

Jeg skvatt litt. Og så ble jeg glad for at de spurte. Vi trenger kunnskap om hvem vi er for å finne ut av hvilke stemmer som skal høres.

\section{LITTERATUR}

1. Chatterjee P, Werner RM. Gender disparity in citations in high-impact journal articles. JAMA Netw Open 2021; 4: e2114509. [PubMed][CrossRef]

2. http://dx.doi.org/10.1038\%2Fd41586-021-02102-8 doi: 10.1038/d41586-021-02102-8. Reardon S. Fewer citations for female authors of medical research. Nature Career News 2021. 10.1038/d41586-021-02102-8. https://www.nature.com/articles/d41586-021-02102-8 Lest 26.9.2021.[CrossRef]

3. Ruzycki SM, Fletcher S, Earp M et al. Trends in the proportion of female speakers at medical conferences in the United States and in Canada, 2007 to 2017. JAMA Netw Open 2019; 2: e192103. [PubMed][CrossRef]

4. King MM, Bergstrom CT, Correl SJ et al. Men set their own cites high: Gender and self-citation across fields and over time. Socius 2017; 3: 1-22. [CrossRef]

5. Lerchenmueller MJ, Sorenson O, Jena AB. Gender differences in how scientists present the importance of their research: observational study. BMJ 2019;367: 16573. [PubMed][CrossRef]

6. Dworkin JD, Linn KA, Teich EG et al. The extent and drivers of gender imbalance in neuroscience reference lists. Nat Neurosci 2020; 23: 918-26. [PubMed][CrossRef]

7. Dworkin J, Zurn P, Bassett DS. (In)citing action to realize an equitable future. Neuron 2020; 106: 890-4. [PubMed][CrossRef] 
8. Rockefeller Inclusive Science Initiative. Et al. For All. Citations as a tool for racial equity, inclusion and justice. https://rurisi.com/citation-guide Lest 26.9.2021.

9. Hofstra B, Kulkarni VV, Munoz-Najar Galvez S et al. The diversity - Innovation paradox in science. Proc Natl Acad Sci U S A 2020; 117: 9284-91. [PubMed][CrossRef]

10. Sumner JL. The Gender Balance Assessment Tool (GBAT): A Web-Based Tool for Estimating Gender Balance in Syllabi and Bibliographies. PS Polit Sci Polit 2018; 51:396-40o. [CrossRef]

Publisert: 11. oktober 2021. Tidsskr Nor Legeforen. DOI: 10.4045/tidsskr.21.0679

(C) Tidsskrift for Den norske legeforening 2023. Lastet ned fra tidsskriftet.no 26. april 2023. 